\title{
PENGARUH KADAR Hb TERHADAP PRESTASI BELAJAR ANAK USIA SEKOLAH KELAS II-VI DI SDN SONOAGENG 6 PRAMBON NGANJUK
}

\author{
Dwi Yanti", Irwanto $^{* * *}$, Arief Wibowo ${ }^{* * *}$ \\ *Akademi Kebidanan Wiyata Mitra Husada, Nganjuk \\ ${ }^{* *}$ Departemen Kesehatan Anak, Fakultas Kedokteran, Universitas Airlangga \\ *** Departemen Biostatistika dan Kependudukan, Fakultas Kesehatan Masyarakat, \\ Universitas Airlangga \\ Alamat Korespondensi: \\ Dwi Yanti \\ Email: d_y4nti87@yahoo.co.id
}

\begin{abstract}
Low hemoglobin $(\mathrm{Hb})$ level said as anemia, would reduce the ability to learn and endurance. Students who suffer from anemia will not have a hight enthusiasm for learning because it is difficult to concentrate. Consequently, anemia indirectly affect the value of courses and learning achievement. The aim of research was to analysis hemoglobin ( $\mathrm{Hb}$ ) level which influents to study achievement school-age-children. Statistic test of the research was linier regression with $\alpha 0.05$ by applying cross sectional approach. The sample taken by simple random sampling, and I got 67 respondents school age - children class II-VI. The result of the research showed that Hb had significantly influent to study achievement school - age - children by analysed regresilinier on grade $p=0.002$.
\end{abstract}

Keywords: hemoglobin level, anemia, study achievement

\begin{abstract}
ABSTRAK
Kadar hemoglobin $(\mathrm{Hb})$ rendah dikenal sebagai anemia, dapat mengurangi konsentrasi belajar dan daya tahan tubuh. Anemia secara tidak langsung memengaruhi Indeks Prestasi hasil belajar. Penelitian ini bertujuan untuk mempelajari pengaruh kadar $\mathrm{Hb}$ terhadap prestasi belajar pada anak usia sekolah. Penelitian ini merupakan penelitian analitik observasional dengan analisis statistik regresi linier dengan a 0,05 dengan cara cross sectional untuk anak usia sekolah kelas II-VI sebagai sampel. Sampel diperoleh dengan teknik simple random sampling yang dilakukan dengan cara lotre sejumlah 67 anak sekolah dasar kelas II-VI. Berdasarkan analisis regresi linier menunjukkan bahwa kadar hemoglobin memiliki pengaruh yang signifikan $\mathrm{p}=0,002$ terhadap prestasi belajar anak usia sekolah.
\end{abstract}

Kata kunci: kadar hemoglobin, anemia, prestasi belajar

\section{PENDAHULUAN}

Prestasi belajar merupakan kemampuan siswa dalam menerima materi yang disampaikan oleh pengajar pada suatu pelajaran dengan nilai tes sebagai tolak ukur keberhasilan (Hamalik, 2002). Prestasi belajar adalah dasar penetapan dari kemampuan seorang siswa dalam rangka menetapkan siswa untuk naik kejenjang pendidikan yang lebih tinggi, (Dalyono, 1997) berpendapat bahwa prestasi merupakan dasar penentuan kesuksesan dari suatu usaha, dengan kata lain prestasi merupakan suatu proses usaha yang dilakukan seseorang secara maksimal berdasarkan seluruh kemampuannya. Sardiman (2007) menyatakan prestasi belajar merupakan hasil yang telah dicapai oleh seorang siswa setelah melampaui proses belajar dalam hitungan/batas waktu tertentu sehingga menghasilkan perubahan 
tingkah laku, pengetahuan dan keterampilan dan perubahan yang dialami siswa dapat dilakukan pengukuran dan penilaian berupa suatu angka atau pernyataan.

Keberhasilan dari setiap usaha yang dilakukan oleh masing-masing individu dikarenakan dari beberapa indikator, yaitu dari indikator pribadi individu sendiri dan indikator yang berasal dari luar individu sendiri. Indikator dari dalam individu antara lain kesehatan jasmani dan rohani, intelegensi, bakat, minat, motivasi dan cara belajar, sedangkan indikator yang berasal dari luar individu yaitu keluarga, keadaan sekolah, masyarakat dan lingkungan (Syah, 2010).

Indikator berpengaruh terhadap prestasi belajar dari dalam individu sendiri yaitu kesehatan di mana status gizi menjadi persoalan yang penting. Persoalan gizi yang sering terjadi pada anak sekolah dasar yaitu terdapatnya kekurangan pada pemenuhan zat gizi besi (anemia gizi), gejala anemia yang sering terjadi pada anak yang mengalami gangguan pemenuhan zat gizi besi yaitu tidak maksimalnya daya tahan tubuh anak sekolah, anak sekolah merasa mudah lelah, pasif dan kurang semangat dalam menerima pelajaran. Masalah yang dapat terjadi karena kekurangan zat gizi dapat dialami oleh semua golongan umur (Almatsier, 2009). Data WHO dalam Worldwide Prevalence of Anemia menunjukkan bahwa "total keseluruhan penduduk dunia yang menderita anemia adalah 1,62 miliar orang dengan prevalensi anak sekolah dasar yaitu 25,4\% dan menyatakan bahwa 305 juta anak sekolah di seluruh dunia menderita anemia" (WPA, 2005).

Berdasarkan nilai rujukan Riskesdes tahun 2013 "proporsi anemia menurut umur, jenis kelamin, dan tempat tinggal, jumlah penderita anemia umur 5-14 tahun adalah $26,4 \%$, jumlah penderita jenis kelamin laki-laki adalah 18,4\%, jenis kelamin perempuan 23,9\%, jumlah penderita yang tinggal di perkotaan 20,6\%, pedesaan $22,8 \%$, sedangkan jumlah penderita anemia di Indonesia mencapai 21,7\%" (Kemenkes RI, 2013).

Terjadinya kekurangan zat besi pada tubuh dapat memengaruhi kemampuan hemoglobin dalam membawa oksigen ke seluruh tubuh. Seluruh reaksi kimia di dalam tubuh memerlukan oksigen sebagai bahan bakar. Penelitian pada anak sekolah telah banyak dilakukan dengan hasil menunjukkan adanya hubungan hemoglobin dengan ketahanan anak dalam belajar. Menurut (Achmad, 2004) menyatakan bahwa konsentrasi anak dalam belajar mengalami penurunan bila anak mengalami kekurangan kadar hemoglobin

Berdasarkan studi awal pada siswa di SDN Sonoageng 6 Kecamatan Prambon Kabupaten Nganjuk tahun ajaran 2014/2015, diketahui bahwa rata-rata nilai lulusan di sekolah tersebut berada di peringkat terbawah dari seluruh sekolah dasar lainnya di wilayah Kecamatan Prambon Kabupaten Nganjuk. Selanjutnya secara khusus dilakukan observasi pada 10 siswa kelas I, II, dan III yang mendapat nilai rapor akhir semester di bawah rata-rata kelas, ditemukan sebanyak 8 siswa (80\%) memiliki status gizi kurus dan sangat kurus serta sebanyak 4 siswa (40\%) memiliki kadar $\mathrm{Hb}<12$ gr/dl atau menderita anemia, hal ini menunjukkan adanya hubungan rendahnya kadar hemoglobin dengan kemampuan belajar anak sekolah dasar.

Zat besi menghasilkan nutrisi yang dibutuhkan pada pertumbuhan tubuh dalam jumlah yang tidak sedikit, jika terjadi kekurangan dalam produksi zat besi maka tubuh mengalami anemia, memperhatikan hal tersebut, tujuan penelitian ini adalah untuk mempelajari pengaruh kadar hemoglobin terhadap prestasi belajar pada anak sekolah.

\section{METODE PENELITIAN}

Penelitian ini merupakan penelitian analitik observasional dengan cara cross sectional. Penelitian ini dilaksanakan di SDN Sonoageng 6 Prambon Nganjuk. 
Populasi anak sekolah yang berjumlah 80 anak setelah melalui proses sampling dengan kriteria inklusi yang telah ditetapkan yaitu anak yang bersedia dijadikan responden dan anak yang bersedia diambil sampel darah untuk memeriksa kadar hemoglobin serta telah mendapat persetujuan dari orang tua, diperoleh sampel sebanyak 67 anak dengan metode simple random sampling, selanjutnya dilakukan tes kadar $\mathrm{Hb}$ dengan metode POCT dengan menggunakan Hbmeter sehingga didapatkan hasil 36 anak sekolah mengalami anemia dengan kadar hemoglobin $<12 \mathrm{~g} / \mathrm{dL}$, sedangkan untuk mengetahui hasil prestasi masing-masing anak ditentukan dengan melihat rata-rata nilai rapor anak pada mata pelajaran yang masuk pada ujian nasional yaitu Bahasa Indonesia, Matematika dan IPA, sehingga didapatkan hanya sebagian kecil anak sekolah yang memiliki prestasi belajar dengan kategori sangat baik (90100)

Variabel baik kadar $\mathrm{Hb}$ dan prestasi belajar masing-masing diuji secara univariat terlebih dahulu, sedangkan untuk mengetahui pengaruh kadar hemoglobin terhadap prestasi belajar pada anak sekolah digunakan uji regresi linier dengan $\alpha 0,05$. Penelitian ini telah dilakukan kaji etik di Universitas Airlangga Surabaya dengan nomor sertivikat 432-KEPK

\section{HASIL}

\section{Karakteristik Responden}

Berikut ini disajikan data karakteristik responden penelitian yang terdiri dari data karakteristik anak:

Berdasarkan tabel 1 diketahui bahwa karakteristik responden anak, sebagian besar responden berjenis kelamin laki-laki sejumlah 41 anak $(61,2 \%)$, sebagian besar responden berada di kelas III sebanyak 18 anak (26,8\%). Jumlah responden pada penelitian ini sebagian besar berjenis kelamin laki-laki karena dari keseluruhan siswa di SDN Sonoageng 6 Prambon Nganjuk sebagian besar berjanin kelamin laki-laki.
Tabel 1. Karakteristik Responen Anak di SDN Sonoageng 6 Prambon Nganjuk Tahun 2016

\begin{tabular}{lcc}
\hline \multicolumn{1}{c}{ Data Umum } & Jumlah & Persentase (\%) \\
\hline Jenis Kelamin & & \\
Laki-laki & 41 & 61,2 \\
Perempuan & 26 & 38,8 \\
Murid Kelas & & \\
II & 15 & 22,4 \\
III & 18 & 26,8 \\
IV & 10 & 14,9 \\
V & 11 & 16,4 \\
VI & 13 & 19,4 \\
\hline
\end{tabular}

\section{Prestasi Belajar}

Daftar prestasi belajar anak di SDN Sonoageng 6 Prambon Nganjuk pada penelitian dapat dilihat pada tabel 2 berikut.

Tabel 2. Prestasi Belajar Anak di SDN Sonoageng 6 Prambon Nganjuk Tahun 2016

\begin{tabular}{|c|c|c|}
\hline $\begin{array}{c}\text { Prestasi Belajar } \\
\text { Anak }\end{array}$ & Jumlah & $\begin{array}{l}\text { Persentasi } \\
\quad(\%)\end{array}$ \\
\hline $\begin{array}{l}\text { Sangat Baik } \\
(80-100)\end{array}$ & 23 & 34 \\
\hline $\begin{array}{l}\text { Baik } \\
(70-79)\end{array}$ & 39 & 58 \\
\hline $\begin{array}{l}\text { Cukup } \\
(60-69)\end{array}$ & 5 & 8 \\
\hline $\begin{array}{l}\text { Kurang } \\
(50-59)\end{array}$ & 0 & 0 \\
\hline $\begin{array}{l}\text { Gagal } \\
(<50)\end{array}$ & 0 & 0 \\
\hline Total & 67 & 100 \\
\hline
\end{tabular}

Berdasarkan tabel 2 diketahui bahwa sebagian besar prestasi belajar anak usia sekolah di SDN Sonoageng 6 Prambon Nganjuk masuk pada kategori prestasi baik sebanyak 39 anak (58\%). 


\section{Kadar Hemoglobin}

Daftar kadar hemoglobin anak di SDN Sonoageng 6 Prambon Nganjuk pada penelitian dapat dilihat pada tabel 3 .

Berdasarkan Tabel 3 diketahui bahwa sebagian besar kadar $\mathrm{Hb}$ anak usia sekolah di SDN Sonoageng 6 Prambon Nganjuk masuk pada kategori di bawah normal/anemia, yaitu sebanyak 36 anak (53,7\%).

Tabel 3. Prestasi Belajar Anak di SDN Sonoageng 6 Prambon Nganjuk Tahun 2016

\begin{tabular}{|c|c|c|}
\hline Kadar Hb Anak & Jumlah & Persentase \\
\hline Anemia $(<12 \mathrm{~g} / \mathrm{dl})$ & 36 & $53,7 \%$ \\
\hline $\begin{array}{l}\text { Tidak Anemia ( } \geq 12 \\
\mathrm{~g} / \mathrm{dl} \text { ) }\end{array}$ & 31 & $46,3 \%$ \\
\hline Total & 67 & $100 \%$ \\
\hline
\end{tabular}

\section{Kadar Hemoglobin terhadap Prestasi Belajar}

Perbandingan kadar $\mathrm{Hb}$ terhadap prestasi belajar anak di SDN Sonoageng 6 Prambon Nganjuk, dapat dilihat dari tabel 4.

Berdasarkan tabel 4 diketahui bahwa sebagian besar anak mengalami anemia memiliki prestasi belajar baik yaitu sebanyak 28 anak (78\%) dan sangat baik sebanyak 4 anak (11\%), sedangkan anak yang tidak mengalami anemia memiliki prestasi belajar sangat baik lebih besar sebanyak 19 anak (61\%), prestasi belajar baik lebih sedikit yaitu sebanyak 11 anak (35\%).

\section{Hasil Analisis \\ Analisis data penelitian ini menggunakan regresi linier. Berikut}

disajikan hasil analisis regresi linier pengaruh kadar hemoglobin terhadap prestasi belajar pada anak sekolah dasar SDN Sonoageng 6 Prambon Nganjuk.

Hasil statistik t untuk variabel bebas, di mana variabel kadar $\mathrm{Hb}$ memiliki nilai Sig. $(p)<\alpha(0,05)$, dengan demikian Ho ditolak untuk variabel kadar $\mathrm{Hb}$ atau dikatakan ada pengaruh yang signifikan kadar $\mathrm{Hb}$ terhadap prestasi belajar anak sekolah dasar di SDN Sonoageng 6 Prambon.

\section{PEMBAHASAN}

Berdasarkan penelitian pada anak sekolah di SDN Sonoageng 6 Prambon Nganjuk diperoleh bahwa, sebagian besar anak memiliki kadar $\mathrm{Hb}$ di bawah normal (dapat dilihat pada tabel 3).

Hasil penelitian ini menunjukkan bahwa terdapat pengaruh kadar hemoglobin $\mathrm{(Hb)}$ secara signifikan terhadap prestasi belajar anak di SDN Sonoageng 6 Prambon Nganjuk. Arah pengaruh adalah semakin rendah kadar $\mathrm{Hb}$ anak, maka semakin rendah prestasi belajar anak, hal ini terjadi karena kurangnya asupan makanan yang adekuat menyebabkan anak berpotensi mengalami penyakit gizi. Penyakit gizi yang menonjol antara lain kekurangan kalori, protein, yodium, vitamin dan zat besi (Wirjatmadi dan Andriani, 2012).

Anemia merupakan gangguan gizi yang sering terjadi pada negara maju maupun negara berkembang. Anemia defisiensi besi sering terjadi pada golongan usia rentan, seperti pada anak-anak, remaja, ibu hamil serta pada pekerja dengan penghasilan yang belum mencukupi kebutuhan. Masalah anemia defisiensi besi dapat berpengaruh

Tabel 4. Kadar Hb Anak di SDN Sonoageng 6 Prambon Nganjuk Tahun 2016

\begin{tabular}{lcccccc}
\hline \multirow{2}{*}{ Kadar Hb } & \multicolumn{5}{c}{ Prestasi belajar } & \multirow{2}{*}{ Total } \\
\cline { 2 - 6 } & $\begin{array}{c}\text { Sangat baik } \\
\mathbf{( 8 0 - 1 0 0 )}\end{array}$ & $\begin{array}{c}\text { Baik } \\
\mathbf{( 7 0 - 7 9 )}\end{array}$ & $\begin{array}{c}\text { Cukup } \\
\mathbf{( 6 0 - 6 9 )}\end{array}$ & $\begin{array}{c}\text { Kurang } \\
\mathbf{( 5 0 - 5 9 )}\end{array}$ & $\begin{array}{c}\text { Gagal } \\
(<\mathbf{5 0})\end{array}$ & \\
\hline Anemia $(<12 \mathrm{~g} / \mathrm{dl})$ & $4(11 \%)$ & $28(78 \%)$ & $4(11 \%)$ & $0(0 \%)$ & $0(0 \%)$ & $36(100 \%)$ \\
Tidak Anemia $(\geq 12 \mathrm{~g} / \mathrm{dl})$ & $19(61 \%)$ & $11(35 \%)$ & $1(4 \%)$ & $0(0 \%)$ & $0(0 \%)$ & $31(100 \%)$ \\
\hline
\end{tabular}


luas terhadap kemampuan belajar dan produktivitas kerja (Almatsier, 2002)

Kekurangan zat besi mengakibatkan terganggunya proses metabolik dalam tubuh, karena terganggunya fungsi dari hemoglobin sebagai alat tranportasi oksigen yang digunakan sebagai bahan bakar. Konsentrasi anak dalam belajar juga menurun akibat kekurangan zat besi. Beberapa penelitian dalam 25 tahun terakhir menunjukkan telah terbukti bahwa kemampuan belajar dan produktivitas kerja dapat dipengaruhi oleh terjadinya anemia, bukti lain menunjukkan terjadinya anemia dapat mengakibatkan gangguan pada perkembangan psikomotor dan kemampuan intelektual serta perubahan perilaku, bila terjadi kekurangan dalam pemenuhan zat gizi maka dapat mengakibatkan terjadinya kekurangan kadar hemoglobin di dalam darah. (Almatsier, 2010).

Defisiensi besi selama masa anak-anak dapat menyebabkan penurunan konsentrasi belajar dan fungsi kognitif, sebaliknya anak dengan kadar $\mathrm{Hb}$ yang baik (non-anemia) memiliki kemampuan belajar yang tinggi, yakni setiap kenaikan $\mathrm{Hb}$ sebesar $1 \mathrm{~g} / \mathrm{dL}$, prestasi belajar akan meningkat 2,3 kali, bahkan IQ total pada anak anemia 12,9 poin lebih rendah dari anak normal. Seorang anak dengan kandungan kadar hemoglobin di dalam darah kurang dari batas normal dapat mengakibatkan terjadinya gangguan pada penerimaan pembelajaran yang disebabkan karena menurunnya kekuatan konsentrasi dari anak tersebut. (Widayanti, 2005).

Menurut World Health Organization (2001), mengatakan bahwa "kadar hemoglobin normal pada anak usia 5-11 tahun adalah 11,5g/dL dan usia 12-14 tahun sebesar $12 \mathrm{~g} / \mathrm{dL}$ ". Menurut Rahmawati (2007), defisiensi besi adalah masalah yang bisa dialami oleh semua golongan umur di masyarakat dan merupakan penyebab terjadinya anemia. Berbagai kajian ilmiah menyatakan bahwa penderita kekurangan zat besi berdampak negatif pada pertumbuhan dan perkembangan anak. zat besi sebagai pigmen pengangkut oksigen $\left(\mathrm{O}_{2}\right)$ dalam darah, sedangkan oksigen sendiri dibutuhkan tubuh pada saat proses pembakaran untuk menghasilkan energi, bila terjadi kekurangan oksigen di dalam tubuh maka dapat menyebabkan terganggunya fungsifungsi sel di dalam tubuh. Defisiensi besi pada anak sering tidak di hiraukan, gejala akibat defisiensi besi antara lain adalah anak mudah lelah, letih, lesu, sering mengeluarkan keringat dingin dan bila keadaan tersebut tidak segera diatasi maka dapat mengganggu kualitas sumber daya manusia dalam hal ini adalah prestasi belajar.

Berdasarkan hasil penelitian yang di lakukan di SDN Sonoageng 6 Prambon mengenai kadar hemoglobin, diketahui 53,7\% responden mengalami anemia. banyaknya responden yang mengalami anemia sejalan dengan penelitian Annas (2011), yang menyatakan bahwa kualitas seumber daya manusia dalam hal ini adalah kecerdasan, produktivitas dan kreativitas salah satu faktor penentunya adalah status gizi.

Kejadian anemia pada responden anak di SDN Sonoageng 6 juga sejalan dengan pernyataan Arisman (2006), bahwa kurangnya kadar hemoglobin bisa terjadi karena asupan zat gizi yang mengandung $\mathrm{Fe}$ tidak sesuai dengan kebutuhan. Pemenuhan asupan nutrisi yang mengandung Fe kurang bisa dikarenakan oleh kemampuan sosial ekonomi masyarakat, sehingga terjadi ketidakmampuan untuk memenuhi konsumsi makanan yang mengandung protein hewani, sayuran hijau dan buah.

Berdasarkan hasil wawancara bersama anak sekolah didapatkan hasil bahwa sebagian besar anak sekolah tidak menyukai sayur atau hanya sesekali mengonsumsi sumber makanan yang mengandung Fe. Hal inilah yang mengakibatkan tidak terpenuhinya kebutuhan Fe. Tidak terpenuhinya asupan sumber makanan yang mengandung $\mathrm{Fe}$ diperoleh dari informasi yang diberikan responden saat pemeriksaan kadar $\mathrm{Hb}$. Anak sekolah yang jarang mengonsumsi sayur, beralasan bahwa tidak menyukai 
sayur karena rasanya cenderung pahit, dengan demikian dapat diketahui bagaimana gambaran perilaku anak sekolah yang kurang mengonsumsi sayur. Hasil wawancara ini sejalan dengan penelitian yang dilakukan oleh Hidayati (2010), menyatakan bahwa kurangnya asupan makanan yang mengandung Fe dan Zink pada anak sekolah dasar di kabupaten Klaten menjadi pemicu terjadinya anemia defisiensi besi

Anemia defisiensi besi pada anak sekolah bermakna terdapatnya kekurangan konsumsi zat makanan yang mengandung zat besi yang terdapat pada sayuran hijau, karena anemia defisiensi besi yang terjadi pada anak bisa diakibatkan karena rendahnya/ kurangnya konsumsi makanan. Anak sekolah yang tidak mendapat asupan nutrisi dengan baik dapat terjadi penurunan daya tahan tubuh sehingga anak sekolah mudah terserang penyakit yang dapat memicu terjadinya anemia pada anak (Waryana, 2010)

McCann dan Ames (2007) mengungkapkan fakta, bahwa kejadian kekurangan zat besi baik yang disertai dengan terjadinya anemia ataupun tanpa disertai anemia, terbukti bis berpengaruh terhadap perkembangan kognitif anak. zat besi adalah mikronutrien yang memiliki peran penting terhadap perkembangan mental dan kognitif seorang anak. zat besi berperan penting pada proses perkembangan otak, yaitu pada proses mielinisasi, metabolisme neuron, dan proses di neurotransmitter.

Arisman (2006), menyatakan bahwa ada beberapa faktor yang dapat berpengaruh terhadap terjadinya anemia defisiensi besi, antara lain karena ketidak seimbangan kebutuhan zat besi pada anak dibandingkan dengan jumlah asupan makanan yang mengandung zat besi. Faktor sosial ekonomi keluarga dan pendidikan orang tua juga dapat memberikan pengaruh terkait dengan kemampuan pemenuhan nutrisi dan pengetahuan tentang kebutuhan nutrisi.

"Hemoglobin disintesis pada sel darah merah dan membawa lebih dari
98,5\% total oksigen dari dalam darah. Hemoglobin terdiri dari bagian yang disebut dengan globin yang terbuat dari polipeptida dan 4 golongan besi" (Gripper, 2009). Anemia defisieni besi pada anak sekolah mengakibatkan anak mengalami penurunan kemampuan intelektual yaitu kemampuan dalam berbicara, mengingat dan berkonsentrasi, hal inilah yang sering dialami anak sekolah yaitu penurunan konsentrasi sehingga mengganggu proses belajar dan berdampak pada prestasi belajar anak sekolah.

Kurangnya kadar hemoglobin di dalam tubuh bukan hanya disebabkan oleh tercukupi atau tidaknya protein dan zat besi di dalam tubuh, tetapi dapat pula dikarenakan adanya zat-zat lain yang fungsinya menghambat penyerapan zat besi dari makanan oleh tubuh (Abdoerrachman, 2007). Keadaan ini menimbulkan dugaan terjadinya anemia defisiensi besi bisa disebabkan oleh kekurangan zat gizi yang mengandung Fe dan zat non gizi.

Efek terjadinya defisiensi besi pada perkembangan dan pertumbuhan anak telah banyak dilakukan penelitian dan dinyatakan pada banyak literatur. Kejadian anemia pada anak dalam jangka waktu 2 tahun pertama mengakibatkan terjadinya gangguan pertumbuhan linier anak (Soliman, 2009). Kejadian anemia pada anak juga dapat menimbulkan terganggunya sistem kekebalan tubuh pada anak (Beard, 2001)

Berdasarkan penelitian yang dilakukan oleh Indriati (2006), terjadinya masalah defisiensi $\mathrm{Fe}$ pada anak sekolah sering disebabkan oleh kurangnya asupan makanan yang mengandung zat besi dan karena anak mengalami kecacingan. Bank dunia menyatakan bahwa "anemia gizi besi pada anak usia sekolah menyebabkan hilangnya $5-10 \%$ prestasi belajar". Penanganan anemia gizi besi dapat dilakukan dengan pemberian suplemen besi dan pengobatan kecacingan. Pemberian suplemen besi dapat ditambahkan dengan pemberian vitamin A, agar lebih efektif dalam meningkatkan kadar 
hemoglobin, karena vitamin A berperan dalam pembentukan sel darah merah (hemopoesis).

Hasil penelitian ini di dukung juga dengan penelitian yang dilakukan oleh Anggraini (2013) yang menyatakan bahwa kadar $\mathrm{Hb}$ dengan nilai rata-rata mid semester memiliki hubungan yang positif dan bermakna secara statistik dengan korelasi kuat. Penelitian yang dilakukan oleh Widayanti (2005), pada SMP Negeri 25 Semarang yang menunjukkan adanya korelasi positif antara kadar hemoglobin dan prestasi belajar.

Penelitian Istiqomah (2012) yang meneliti kejadian Anemia pada remaja putri dikaitkan dengan motivasi belajar, menyimpulkan bahwa remaja putri cenderung berkurang motivasi belajarnya bila sedang mengalami menstruasi, ketika dilakukan pemeriksaan kadar hemoglobin saat menstruasi pada remaja putri sering terjadi penurunan kadar hemoglobin, sehingga remaja putri cenderung mengalami anemia pada saat menstruasi. Gejala yang ditimbulkan antara lain adalah tidak semangat dan lesu saat menerima pelajaran di sekolah.

Penelitian ini juga sejalan dengan penelitian yang dilakukan oleh Hujanin (2011) menunjukkan hubungan yang kuat antara kadar $\mathrm{Hb}$ dengan prestasi belajar mahasiswa penghuni asrama Poltekes Kemenkes Jakarta III di mana ditemukan mahasiswa memiliki kadar hemoglobin darah $<12 \mathrm{~g} \%$ ada indikasi menderita anemia, hal tersebut diakibatkan kebiasaan pola makan mahasiswa jarang menghadirkan lauk hewani seperti daging sebagai makanan sehari-hari, yang merupakan sumber besi hem yang mudah diserap oleh tubuh dibandingkan besi non-hem yang berasal dari sumber nabati.

Faktor yang tidak kalah penting untuk mencegah anak sekolah mengalami anemia adalah dengan memperhatikan asupan makanan yang dikonsumsi setiap harinya, di mana zat makanan dari sumber makanan hewani lebih cepat diserap tubuh dan memudahkan peningkatan kadar hemoglobin, perlu diperhatikan pula asupan nutrisi lain yang dapat membantu penyerapan kandungan zat besi dalam makanan kedalam tubuh dengan lebih maksimal, antara lain dengan mengonsumsi vitamin $\mathrm{A}, \mathrm{C}$, dan juga menambah konsumsi makanan yang mengandung zink, serta asupan zat besi seperti daging merah, hati, ikan ayam, dan sayur-sayuran serta dibutuhkan pula porsi yang cukup dari sumber nabati tersebut untuk mencukupi kebutuhan gizi dalam satu hari, bila kebutuhan tidak terpenuhi maka dapat menimbulkan terjadinya defisiensi besi dalam tubuh dan berlanjut pada terjadinya anemia.

Menurut Zalihah (2007) menyatakan bahwa setiap makanan yang dikonsumsi oleh seseorang harus memenuhi unsur zat tenaga, zat pembangun dan zat pengatur yang berguna untuk memenuhi zat gizi pada anak sekolah sebagai sumber energi yang bermanfaat untuk melakukan berbagai aktivitas di sekolah.

Prestasi belajar anak juga tidak sepenuhnya dipengaruhi oleh kadar hemoglobin. Ada beberapa faktor lain yang juga memengaruhi prestasi belajar antara lain faktor dari individu sendiri, misalnya bakat, minat, dan motivasinya dalam belajar. Adapula faktor dari luar anak misalnya lingkungan keluarga di mana status sosial ekonomi dan pendidikan orang tua sangat berpengaruh terhadap kebiasaan keluarga, misalnya jenis makanan yang dikonsumsi atau penerapan pola asuh dalam mendidik anak.

Kejadian ini menggambarkan bila seseorang memiliki kadar hemoglobin normal atau tidak mengalami anemia tidak dapat dipastikan orang tersebut memiliki prestasi belajar yang baik jika tidak didukung dengan faktor-faktor lain yang berpengaruh terhadap prestasi belajar anak sekolah antara lain semangat dan motivasi belajar serta dukungan keluarga dan faktor pendukung lain misalnya fasilitas sekolah tempat belajar, hal ini sesuai dengan pernyataan 
Widayanti (2005) bahwa motivasi belajar turut berpengaruh dalam pencapaian prestasi belajar.

Faktor lain dari luar individu juga berasal dari lingkungan sekolah, di mana kondisi lingkungan sekolah, fasilitas yang ada di sekolah untuk menunjang proses belajar mengajar serta cara guru dalam menyampaikan materi pembelajarn juga dapat berpengaruh terhadap pemahaman siswa dalam belajar sehingga berpengaruh terhadap prestasi belajar anak sekolah.

\section{SIMPULAN}

Prestasi belajar pada anak sekolah dasar di SDN Sonoageng 6 Prambon Nganjuk sangat sedikit yang berada pada kategori sangat baik, hal ini tidak terlepas dari prevalensi anemia pada anak sekolah dasar di SDN Sonoageng 6 Prambon Nganjuk yang tinggi.

Pola konsumsi anak di SDN Sonoageng 6, diketahui masih sangat kurang dalam mengonsumsi zat makanan yang mengandung zat besi atau zat makanan yang dapat meningkatkan penyerapan zat besi, sehingga lebih dari setengah anak di SDN Sonoageng 6 mengalami anemia.

Penanggulangan anemia pada anak sekolah, sekolah diharapkan bekerja sama dengan puskesmas atau dinas kesehatan terkait untuk memberikan penyuluhan pada orang tua anak sekolah tentang pengaruh rendahnya kadar hemoglobin terhadap prestasi belajar siswa, sehingga orang tua lebih memperhatikan asupan makanan bergizi untuk anaknya agar dapat meningkatkan prestasi belajar.

Dinas kesehatan terkait hendaknya memberikan tambahan suplemen zat besi agar lebih cepat dalam meningkatkan kadar hemoglobin pada anak sekolah.

\section{DAFTAR PUSTAKA}

Abdoerrachman, M.H. 2007. Ilmu Kesehatan Anak. edisi 4. Jakarta: Bagian Ilmu Kesehatan Anak Fakultas Kedokteran Universitas Indonesia.
Achmad D. S. 2004. Ilmu Gizi untuk Mahasiswa dan Profesi Jilid II. Dian Rakyat. Jakarta.

Almatsier S. 2009. Prinsip Dasar Ilmu Gizi. Gramedia Pustaka Utama. Jakarta.

Almatsier S. 2010. Prinsip Dasar Ilmu Gizi. Jakarta: PT. Gramedia Pustaka Utama.

Almatsier, S. 2002. Prinsip Dasar Ilmu Gizi. Cetakan ke -2. Jakarta: Gramedia Pustaka Utama.

Annas, M. 2011. Hubungan Kesegaran Jasmani, Hemoglobin, Status Gizi dan Makan Pagi terhadap Prestasi Belajar. Jurnal Media Ilmu Keolahragaan Indonesia: 1(2).

Anggriani. 2013. Hubungan Indeks Massa Tubuh dan Kadar $\mathrm{Hb}$ terhadap prestasi belajar siswa di SMP Negeri 2 Bandar Lampung. Jurnal Ilmiah Pendidikan Khusus: 1(258-264)

Arisman M.B. 2006. Gizi Dalam Daur Kehidupan. Buku Ajar Ilmu Gizi. Jakarta: EGC

Beard, JL. 2001. Iron Biology in Immune Function, Muscle Metabolism and Neuronal Funtioning. American Society for Nutritional: 1 (2086-3098).

Dalyono. M. 1997. Psikologi Pendidikan. Rineka Cipta. Jakarta.

Gropper, S.S. 2009. Advance Nutrition and Human Metabolism Fifth edition. Canada: Wordworth Cengange Learning.

Hamalik, O. 2002. Psikologi Belajar dan Mengajar. Sinar Baru Algensindo. Bandung.

Hidayati L. 2010. Anemia dan Prestasi Belajar Anak Sekolah Dasar. Jurnal Kesehatan: 3 (2).

Husjain, D., Chairlan, Mardiana. 2011. Analisis Hubungan Kadar Hemoglobin dengan Prestasi Belajar Mahasiswa Penghuni Asrama Poltekes Jakarta III. Jurnal Ilmu dan Teknologi Kesehatan: 1(93-100).

Indriati, I. 2006. Pengaruh Suplementasi Besi dan Vitamin a terhadap Kadar Hemoglobin dan Prestasi Belajar Anak Sekolah Dasar Negeri 3 Neglasari Kota Banjar. Jurnal kesehatan Forikes: 2 (3). 
Istiqomah. 2012. Hubungan antara Kadar $\mathrm{Hb}$ dengan Prestasi Belajar Mahasiswa Prodi DIII Kebidanan Stikes Widya Husada Semarang. Tesis. Fakultas Teknik Universitas Wahid Hasyim Semarang.

Murray-Kolb, LE., and Beard, JL. 2007. Iron Treatment Normalizes Cognitive Functioning in Young Women. Am Clin Nutr. American Society for Nutrition.

Rahmawati, W. 2007. Association between Iron Status and helminth infection, and iiflammation status among 12-20 weeks pregnant women in Karanganyar and Demak. Info Pangan dan Gizi: 14(2)

Sardiman, AM. 2007. Aktifitas dan Motifasi Belajar Mengajar. Jakarta: Raja Grafindo.

Soliman, AT., Al Dabbagh, MM., Habboub, AH., Adel, A., Al Humaidy, N., Abushahin, A. 2009. Liniar Growth in Children with Iron Deficiency Anemia Before and After TreatmentI. Journal of Tropical Pediatries: vol. 58 issue 5.

Syah, M. 2010. Psikologi Pendidikan. Raja Grafindo Persada. Jakarta.

Kemenkes, RI. 2012. Ada Tiga Kelompok Permasalahan Gizi di Indonesia. Departemen Kesehatan. Jakarta.

Kemenkes, RI. 2013. Penyajian Pokok-Pokok Hasil Riset Kesehatan Dasar 2013. Badan Penelitian dan Pengembangan Kesehatan Departemen Kesehatan. Jakarta.
Kemenkes, RI 2008. Laporan Nasional Riskesdas 2007. Badan Penelitian dan Pengembangan Kemenkes. Jakarta.

World Prevalence of Anemia (WPA). 2005. Laporan World Health Organization 1993-2005.

Wirjatmadi, B., Andriani, M. 2012. Peranan Gizi dalam Siklus Kehidupan. Jakarta: Kencana.

Widayanti, A. 2005. Hubungan Kdar Hemoglobin dengan Prestasi Belajar Siswi SMP Negeri 25 Semarang. Skripsi. Fakultas Kesehatan Masyarakat: Universitas Negeri Semarang.

Waryana. 2010. Pengantar Pangan dan Gizi. Jakarta: Penebar Swadaya.

Widyastuti, A.P. 2014. Hubungan Kadar Hemoglobin Siswa dengan Prestasi Belajar di Sekolah Dasar Negeri I Bentangan Wonosari Kabupaten Klaten. Naskah Publikasi. Surakarta: Fakultas Ilmu Kesehatan. Universitas Muhammadiyah. WHO. 2001. Iron Deficiency Anemia Assesment Prevention and Control. A Guide for Programme Managers. World Health Organization. Genewa.

Zalihah. 2010. Buku Gizi dan Kesehatan Masyarakat. Departemen Gizi dan Kesehatan Masyarakat. Jakarta: Rajawali Press. 